\title{
Determinants of property rate default: evidence from the Ashanti Region, Ghana
}

\section{Dadson Awunyo-Vitor}

Department of Agricultural Economics, Agribusiness and Extension Faculty of Agriculture Kwame Nkrumah University of Science and Technology Kumasi

\section{Eric Oduro Osae}

Institute of Local Government Studies

Accra, Ghana

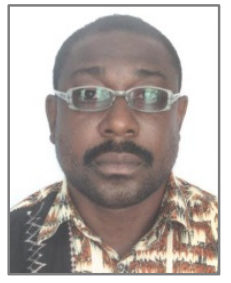

\section{Sterling Donani}

Bosomtwe District Assembly

Ashanti Region

Ghana

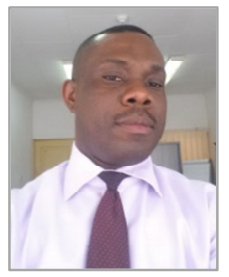

\begin{abstract}
This study seeks to assess the determinants of property rates default in the Ashanti Region of Ghana. A multi-stage sampling technique was used to study 540 respondents from one municipal and five district assemblies within the region. A structured questionnaire collected data from the sampled respondents. Descriptive statistics (means, frequency distribution and percentages) and the probit regression model were then used to analyse the data with the help of SPSS and STATA respectively. The study found that most respondents who default are not aware of their obligation to pay property rates, and those who are aware fail to pay because they don't know where to go to pay, or think the rate is too high. The study also revealed that a demographic characteristic such as income level, property value and property location influences rates of default. The study recommends raising awareness about the need to pay property rates and the penalty for any default.
\end{abstract}

Key words: district assemblies, property rates, local governance, Ghana. 


\section{Introduction}

Decentralisation involves a deliberate and planned transfer of resources and some level of power and responsibilities to peripheral institutions (Duncan, 2007). There are three components of decentralisation, namely, political decentralisation, administrative decentralisation and fiscal decentralisation. In the recent past, the concept of decentralisation has gained popularity in developing countries, including Ghana. In 1988, Ghana implemented comprehensive reform in its local governance structure and adopting decentralisation as an alternative development strategy. This strategy included political, administrative and fiscal decentralisation and aimed to promote effective and efficient governance at the local level (Ayee, 2008).

The Constitution of Ghana also encourages parliament to ensure that functions, powers and responsibilities - as well as resources - are transferred from central government to local government units (namely metropolitan, municipal and district assemblies (MMDAs). The goal of this activity is to make MMDAs responsive to the needs of local people.

It is widely accepted that an effective and efficient revenue mobilisation system at local level is critical for the successful running of local government (Ellis et al., 2007; Oluwu \& Wunsah, 2008). As part of Ghana's fiscal decentralisation, MMDAs are thus responsible for the generation of revenue to support their activities. This is to be achieved through the imposition of rates, taxes and charges within their jurisdiction. MMDAs are empowered by the Local Government Act, 1993 (Act 462) to raise revenue internally under the leadership of elected members of the assembly or those appointed by the district chief executive (DCE). Elected members should be answerable to the local people who elected them and the DCE to the central government who appointed him or her. This has led to devolution in both revenue mobilisation and spending powers to local government authorities (Fjeldstad \& Semboja, 2001).

To encourage local authorities to mobilise more funds, the amount of grant funding available from central government via its Assemblies Common Fund (ACF) is dependent on the amount of money the district generates internally through rates, taxes and charges. Income from these sources is known as Internally Generated Funds (IGF).

However, the amounts raised internally by the MMDAs always fall short of those budgeted. For example, a report by Ghana's National Development Planning Commission (NDPC) revealed that, in 2009, MMDAs' IGF averaged only $18.7 \%$ of the total revenue received by the assemblies from all sources including inflow from Assemblies Common Fund. In all, the assemblies mobilised less than $20 \%$ of the total resources they had budgeted for (NDPC, 2010).

At the local level, the major sources of revenue currently include: user fees and charges; revenue from specific trades; property rates; and fees paid by users of certain facilities provided by local authorities 
(in Ghana's case the assemblies). Examples of user fees and charges include: car parking charges at commercial centres; tolls for using market facilities; and fees for tender application forms. Examples of revenue from specific trades include: slaughter fees; fees related to the brewing and sale of alcohol; fees for transporting charcoal and wood; timber permits; and permits for stage plays and public entertainment. Examples of property rates and fees include: rent on commercial buildings or land owned by the assembly; and property rates paid by owners of property situated within the jurisdiction of the assembly. Other sources of revenue available to the assemblies include fines and penalties as well as profits and dividends from investments.

Boamah (2013) asserted that property tax is one of the most productive local taxes as it is charged on immovable assets. Property tax can help local government raise funds for local development (Lall \& Deichmann, 2006) and reduce dependence on central government funding (Transberg, 2004; McCluskey \& Beve, 2007). This tax is also more acceptable to local people as it is perceived to be fair (Davis et al., 2004; Monkam, 2009). Bahl (2009) concluded that property tax is one of the best taxes for local authorities in developing countries to concentrate on, due to the low cost associated with its collection and its potential to generate a sustainable and predictable stream of revenue - a view shared by McCluskey et al. (2003). Needham (2000) also noted that property tax can be used to fund the provision of infrastructure and municipal services.

In Ghana, property rates are the most important source of revenue for most MMDAs and account for about 44-60\% of revenue collected (Appiah et al., 2000). However, despite the contribution of property rates and their potential for improving IGF and unlocking income from central government, MMDAs face several challenges in mobilising this revenue. If the factors influencing non-payment are identified, it will be easier to address those challenges. Thus, the aim of this study is to investigate those factors, using the Ashanti Region of Ghana as a case study.

\section{Literature Review}

Property tax has a long history. In England, property tax was introduced in 1601 by the Poor Relief Act, which aimed to raise funds to support vulnerable individuals who were unable to maintain themselves. In Britain, tax assessors who collected tax for landlords used ownership records of property to estimate an individual's ability to pay tax (Mathur et al., 2009). Overtime, the taxes based on ownership of property came to be regarded as property tax (Mou, 1996). This was later developed into a rated scale which is typically based on the rental or sale value of a property.

In America, property tax was introduced in 1796 and was linked to the economic and political conditions of the time (Illinois Department of Revenue, 2001). It was a major source of local government revenue and was referred to as taxation of wealth. This tax was in line with the prevailing egalitarian ideology of the time (Chipeta, 2002). 
Different countries use different rating systems to determine the tax payable. Some use the capital value of land, while others use the capital value of land and buildings, either jointly or separately. Some Commonwealth countries use the value of a building as a basis of imposing property tax - and this is the case in Ghana.

Property tax is the most popular source of municipal revenue in a number of countries. For example, in the United Kingdom it generates a large proportion of local government revenue. Property tax is an ad valorem tax because the tax payable is determined by the value of the property. This tax is normally imposed and administered by local authorities, hence it may be characterised as a local tax (Illinois Department of Revenue, 2001). In Canada, property tax on real estate is the major source of revenue for many local authorities - and, although the amount of tax payable varies from municipality to municipality, all municipalities use common assessment criteria to determine rating bands, typically the market value of the property.

In Ghana, property tax is an element of IGF. Local development is financed by a mixture of IGF and externally generated funds (EGF) (Crawford, 2004). Local authorities are not completely dependent on central government but have some revenue-raising powers (Crawford, 2004). Under decentralisation, as district assemblies are legally permitted to generate their own funds, MMDAs are responsible for raising revenue, under an elected leadership. This revenue generation at the local level is in the form of local rates and receipts, market taxes, fines, fees, licences, rents and dividends/profits from investment.

The taxes and rates are classified as basic rates and property rates, and are payable by individuals and organisations who own immovable properties situated in the jurisdiction of the assembly (Bird \& Slack, 2002; Crawford, 2004). These taxes are recurrent in nature and are usually charged yearly. All buildings within the jurisdiction of an assembly are eligible for property tax unless specifically exempt by Section 99 of the Local Government Act, 1993. Assemblies may, however, grant complete or partial exemption to properties used for charitable, religious or other public purposes, or for a good cause.

Property rates have the potential to improve the income of the assemblies and play an important role in sustaining assemblies financially to implement projects and programmes (Bird \& Slack, 2002).

Property tax is assessed as a percentage of a property's value. This may relate to the annual rental value of the property or its capital value. In Ghana the tax is based on capital value, determined by a valuation from the Land Valuation Division of the Lands Commission, or its representative. Under Section 95 of the Local Government Act, 1993, an assembly is required to raise sufficient rates to achieve its intended purposes. Additionally, Section 96 states: 'A rating authority may, subject to this Act, levy general or special rates of such amount as it considers necessary having regard to Section 95(1) indicated above.' 
Before Ghana's independence, property tax yields were very high. In urban areas especially, where expatriates had businesses and properties, the tax collected exceeded the various targets set and became the most important source of IGF for basic local recurrent and other development expenses. However, property tax revenue started to decline in the early 1960s when most businesses were taken over by African merchants who often refused to pay the required property taxes. This situation still prevails and currently property tax revenue in Ghana represents a low percentage of revenue for local government, particularly rural district assemblies. For example, Ahafo Ano North District Assembly collected only $11 \%$ of its budgeted property rates in 2013 (District Assembly Annual Report, 2014).

\section{Methodology}

\section{Data collection procedure}

A multi-stage sampling technique was used to select respondents for the study. In all, one municipal and five district assemblies were selected out of 27 assemblies within the Ashanti Region. The assemblies were chosen in order to have representation from two groups: metropolitan/municipal assemblies and district assemblies. The region's assemblies were divided into the two groups, and a simple random sampling method was used to select one municipal and five district assemblies from the two groups respectively.

The electoral areas within the major town of each assembly district were then identified, and two electoral areas in each town were selected - one recently developed area (new site) and one old town with little development. For each selected electoral area the local (elected) assemblyman helped the research team to prepare a list of respondents following which a simple random sampling technique was used to select 540 respondents

Information was solicited from respondents via a structured questionnaire, which covered their socioeconomic characteristics, whether they paid property rates, and their reasons. Table 1 below lists the assemblies selected for the study, their capital towns and the number of respondents from each assembly.

Table 1 Selected Assemblies, their Capital Towns and Number of Respondents

\begin{tabular}{|l|l|c|}
\hline Selected District and Municipal Assemblies & Capital & $\begin{array}{l}\text { Number of } \\
\text { Respondents }\end{array}$ \\
\hline Adansi North & Fomena & 70 \\
\hline Ahafo Ano North & Tepa & 80 \\
\hline Ejisu-Juaben (municipal assembly) & Ejisu & 150 \\
\hline Ejura/Sekyedumase & Ejura & 100 \\
\hline Asante Akim South & Juaso & 60 \\
\hline Kwabre & Mamponteng & 80 \\
\hline Total & & $\mathbf{5 4 0}$ \\
\hline
\end{tabular}

Source: Authors' own construct 2013 


\section{Analytical framework}

Descriptive statistics (mean, frequency distribution, percentages) were collated on the socioeconomic characteristics of the respondents. Kendall's coefficient of concordance $(W)$ analysis was used to rank the reasons given by respondents for non-payment of property rates. The degree of agreement of the rankings by the respondents was then measured with $W$.

The value of $W$ ranges from 0 to 1 . In deriving $W$, let $T$ represent the sum of ranks for each reason given which is being ranked. The variance of the sum of ranks is given by:

$$
\operatorname{Var}_{T}=\frac{\sum T^{2}-\left(\sum T\right)^{2} / n}{n}
$$

where $\operatorname{Var}$ denotes variance and $n$ denotes the number of reasons. The maximum variance of $T$ is given by:

$$
m^{2}\left(n^{2}-1\right) / 12
$$

where $m$ is the number of respondents. The formula for Kendall's coefficient of concordance $(W)$ is:

$$
W=\frac{\left(\sum T-\left(\sum T\right)^{2} / n\right) / n}{m^{2 *}\left(n^{2}-1\right) / 12}
$$

By simplifying the third equation above the computational formula for $W$ becomes:

$$
W=\frac{12\left[\sum T^{2}-\left(\sum T\right)^{2} / n\right]}{m n^{2}\left(n^{2}-1\right)}
$$

Additionally, the probit regression model was used to evaluate the factors that influenced respondents' property rates payment default. This model was selected because it constrains the estimated probabilities to between 0 and 1 . It also relaxes the constraint upon the dependent variables which are constant across different predicted values of dependent variable (Nagler, 1994). The probit model also assumes that there is a latent variable $Y^{*}$ which is an unobservable variable but which influences the dependent variable $Y$. When $Y^{*}$ reaches a threshold then a respondent may decide to default $(Y=1)$, but if it is below the threshold then the respondent may decide to pay the property rates $(Y=0)$. The dependent variable $Y$ is the property rates default status (i.e. for a property owner who has defaulted in payment this status is dummied ' 1 '; for a property owner who has paid his/her property rates it is ' 0 ').

The relationship between the unobservable latent variable $Y^{*}$ which influences the dependent variable $Y$ and the independent variables can be specified in a probit model as follows:

$$
\begin{aligned}
Y_{i}^{*}=\delta_{0}+\sum_{j=1}^{11} \delta_{j} X_{i}+\mu_{i} & \\
& Y_{i}=1 \text { if } Y^{*}>0 \\
Y_{i} & =0 \text { if } Y^{*} \leq 0
\end{aligned}
$$


Where $X_{1}, X, X_{3} \ldots X_{10}$ represent a vector of random variables (independent variables) and $\delta$ represents a vector of unknown parameters and $\mu_{i}$ represents a random disturbance term (Nagler, 1994).

The empirical probit model specified to analyse the determinants of property rate defaults by the respondents was expressed as follows:

$$
\begin{aligned}
& Y_{i}+\delta_{0}+\delta_{1} \mathrm{GEN}_{i}+\delta_{2} \mathrm{AGE}_{i}+\delta_{3} \mathrm{MARI}_{i}+\delta_{4} \mathrm{EDU}_{i}+\delta_{5} \mathrm{NDEP}_{i}+\delta_{6} \mathrm{INCOM}_{i}+\delta_{7} \mathrm{PRATE}_{i}+ \\
& \delta_{8} \mathrm{PNALTY}_{i}+\delta_{9} \mathrm{LOCA}_{i}+\delta_{10} \mathrm{VALUE}_{i}+\delta_{11} \mathrm{MUSE}_{i}+\mu_{i}
\end{aligned}
$$

The description, measurement and a priori expectation of the variables used in the probit model are presented in Table 2.

\begin{tabular}{|c|c|c|c|}
\hline Variables & Description & Measurement & Expected Sign \\
\hline Gender [GEN] & Gender of the property owner & $\mathrm{D}=1$ if male, 0 if female & $+/-$ \\
\hline Age [AGE] & Age of the property owner & Years & $+/-$ \\
\hline Marital status [MARI] & Marital status & $\begin{array}{l}D=1 \text { if married, } 0 \\
\text { otherwise }\end{array}$ & - \\
\hline Age square [AGESQ] & $\begin{array}{l}\text { Square of the age of the property } \\
\text { owner }\end{array}$ & Years & - \\
\hline Education [EDU] & $\begin{array}{l}\text { Number of years of formal } \\
\text { education of the property owner }\end{array}$ & Years & - \\
\hline Number of dependants [NDEP] & $\begin{array}{l}\text { Number of people depending on } \\
\text { the property owner }\end{array}$ & Number & + \\
\hline Income [INCOM] & $\begin{array}{l}\text { Average annual income of the } \\
\text { property owner }\end{array}$ & Ghana cedis & - \\
\hline Perception of rate [PRATE] & $\begin{array}{l}\text { How the property owner perceives } \\
\text { the rate charged }\end{array}$ & $\mathrm{D}=1$ if high, 0 otherwise & + \\
\hline Awareness of penalty [PNALTY] & $\begin{array}{l}\text { Awareness of penalty for default in } \\
\text { paying property rates }\end{array}$ & $\begin{array}{l}\mathrm{D}=1 \text { if aware. } 0 \\
\text { otherwise }\end{array}$ & - \\
\hline Location of property [LOCA] & Where the property is located & $\begin{array}{l}\mathrm{D}=1 \text { new site, } 0 \\
\text { otherwise }\end{array}$ & - \\
\hline Value of property [VALUE] & $\begin{array}{l}\text { How much the property would sell } \\
\text { for }\end{array}$ & Ghana cedis & - \\
\hline Major use [MUSE] & $\begin{array}{l}\text { Whether used mainly for } \\
\text { residential or for commercial } \\
\text { purposes }\end{array}$ & $\begin{array}{l}D=1 \text { if commercial, } 0 \\
\text { otherwise }\end{array}$ & - \\
\hline
\end{tabular}

Table 2 Description of the Explanatory Variables Used in the Regression Model

Source: Authors' own construct 2013

\section{Findings and Discussion}

\section{Socioeconomic characteristics of respondents}

The study collected data on a number of characteristics, discussed here and summarised in Table 3.

Gender: The property owners interviewed were $68.2 \%$ male and $31.8 \%$ female. This finding indicates that women still lag behind men in terms of property ownership despite forming the majority of Ghana's population (Ghana Statistical Service, 2012).

Age: The majority (54.5\%) of property owners interviewed fell within the age ranges of 41-60 years, followed by $36.4 \%$ of owners within the age ranges of $21-40$ years. The remaining $9.1 \%$ are aged above 60 years. 
Education: Data on the educational level of respondents indicates that the majority $(34.5 \%)$ of interviewees have had junior high school or middle school education. The next most populous group is those with a secondary school or vocational qualification (24.5\%). Those with tertiary and primary levels of education form $20.9 \%$ and $11.8 \%$ of respondents respectively.

Occupation: It was observed that $15.5 \%$ of respondents are engaged in farming activities, while $37.3 \%$ are employed by or on the payroll of the government. Private sector employees constitute $26.4 \%$ of the sample, while those engaged in petty trading make up $20.9 \%$. The low proportion of farmers might be due to the fact that farmers' income levels are low and they lack the collateral to access credit to support infrastructural property development. By contrast, government and private sector employees can make savings from their salaries to support property ownership, and can also use their salaries as collateral to access credit to support building projects.

Property use: The study also revealed that $67.3 \%$ of the properties under study were residential while 28.2\% were commercial (ranging from hotels, guest houses and restaurants to shops and stalls). The remaining $4.5 \%$ were used for both residential and commercial purposes.

Table 3: Socioeconomic Characteristics and Payment Status of Respondents

\begin{tabular}{|l|l|c|c|}
\hline Characteristics & Groupings & Frequency & Percentage \\
\hline Gender & Male & 368 & 68.2 \\
\hline & Female & 172 & 31.8 \\
\hline & $21-40$ years & 197 & 36.4 \\
\hline & $41-60$ years & 294 & 54.5 \\
\hline Formal education & Above 60 years & 49 & 9.1 \\
\hline & Pone & 44 & 8.2 \\
\hline & JHS/Middle school & 64 & 11.8 \\
\hline & SHS/Sec/Tech/Vocational & 186 & 34.5 \\
\hline & Tertiary & 134 & 24.9 \\
\hline Major occupation & Farming & 113 & 20.9 \\
\hline & Petty trading & 84 & 15.5 \\
\hline & Government employee & 113 & 20.9 \\
\hline & Private sector employee & 201 & 37.3 \\
\hline Types of property & Residential & 143 & 26.4 \\
\hline & Commercial & 363 & 67.3 \\
\hline & Part commercial, part residential & 152 & 28.2 \\
\hline Location & Old town & 24 & 4.5 \\
\hline & New town & 207 & 38.3 \\
\hline Respondents & Defaulters & 333 & 61.7 \\
\hline & Non-defaulters & 391 & 72.4 \\
\hline
\end{tabular}

Source: Field Survey, 2013

The fact that the majority of properties in the survey were being used for residential purposes reflects the need for accommodation for workers. The majority $(61.7 \%)$ of the properties in the survey are located in newer areas, but $38.3 \%$ of the properties are in older areas. These are mostly inherited 
properties, often houses used for accommodation. The fact that the majority of properties are located in new areas reflects the high rate of infrastructure development in the region.

Payment of rates: Finally, and perhaps most importantly for this study, the survey found that in all, a little over a quarter of respondents (27.4\%) have paid their property rates for the 2012 fiscal year to the various assemblies.

\section{Reasons for non-payment of property rates}

As indicated above, only $27.4 \%$ of survey respondents had paid their property rates in 2012 . This study attempts to identify the major reasons why those defaulting did not pay property rates. Respondents were asked to select all applicable reasons why they default on payment of property rate and rank the selected reasons. The result is presented in Table 4.

Table 4 Reasons for Non-payment of Property Rates by Defaulters

\begin{tabular}{|l|c|c|c|}
\hline Reasons for Non-Payment & Frequency & Percentage & Rank \\
\hline I am not aware of property rate & 152 & 38.71 & $1^{\text {st }}$ \\
\hline The amount charged is too high/expensive & 50 & 12.90 & $4^{\text {th }}$ \\
\hline I don't know where I have to pay & 101 & 25.81 & $2^{\text {nd }}$ \\
\hline I don't see the need to pay & 21 & 5.38 & $5^{\text {th }}$ \\
\hline The collectors don't come to collect & 67 & 17.20 & $3^{\text {rd }}$ \\
\hline Number of respondents & 391 & & \\
\hline Coefficient of concordance $(W)$ & $0.6875(68.75 \%)$ & \\
\hline
\end{tabular}

Source: Field Survey, 2013

The study identified five major reasons why some respondents did not pay property rates. The test of significance in terms of $F$ distribution of the degree of agreement or concordance $(W)$ between the rankings of the reasons for non-payment of property rates by the respondents is fairly high, with above $60 \%$ levels of agreement between the rankings of the respondents. The most important reason given for non-payment of property rates is lack of awareness of any obligation to pay. This reason was mentioned by $151(38.71 \%)$ of the defaulters and as such is ranked first.

These respondents indicated that they had never heard of any rates payable on their properties, and in addition, no one had ever approached them to pay such a tax. This might be due to the lack of a sensitisation programme in some district assemblies as a result of inadequate logistics and personnel. It is possible this response may be motivated by the fact that the respondents are afraid of the consequences of not paying property rate.

The second most important reason given for defaulting on property rates is lack of knowledge about where they should be paid. About $25.81 \%$ of defaulters claimed they do not know where to go to make the necessary payment. This could be attributable to an absence of revenue collection points in most of the study districts. 
The reason ranked third, as Table 4 shows, relates to revenue collectors not collecting the property rates. About $17.20 \%$ of defaulters indicated that this is why they do not pay their property tax, thus inadequate personnel may affect property rate collection by the MDAs negatively. The assemblies need to improve their human resource capacity, particularly in the area of revenue collection, in order to encourage payment.

The reason ranked fourth is the amount of tax imposed on the property. About $12.90 \%$ of defaulters claimed the sum is too high and they could not afford the payment. Another $5 \%$ of defaulters gave as a reason, the belief that they do not need to pay property tax because they constructed their own properties. They noted that they would not receive any benefit in return for payments made, since they do not have water facilities, roads or electricity in their communities.

\section{Regression results}

The result of the probit model on the factors influencing property rate default is reported in Table 5 . The regression gave Pseudo $\mathrm{R}^{2}$ as 0.552 with a probability value of 0.000210 . This indicates that at least one of the explanatory variables included in the model as a coefficient is statistically significant, meaning the coefficient is different from zero. The fitness of the model was evaluated using the Hosmer and Lemeshow goodness-of-fit test. The result gave a P-value of 0.9602, which suggests that the model fits reasonably well. Given the Pseudo $\mathrm{R}^{2}$ value, the P-value for the F-statistics and the Pvalue for the Hosmer and Lemeshow goodness-of-fit test, it is concluded that the probit model used has integrity and is appropriate.

Table 5 Probit Regression Results on the Factors Influencing Probability of Property Rate Default

\begin{tabular}{|l|c|c|c|c|c|}
\hline Variables & Coefficient & $\begin{array}{l}\text { Standard } \\
\text { Deviation }\end{array}$ & T-stats & $\begin{array}{l}\text { P- } \\
\text { value }\end{array}$ & $\begin{array}{l}\text { Marginal } \\
\text { Effect }\end{array}$ \\
\hline Gender [GEN] & $-0.2358^{\star * *}$ & 0.00332 & -71.024 & 0.000 & 0.0250 \\
\hline Age [AGE] & 0.4538 & 0.2894 & 1.568 & 0.625 & 0.2001 \\
\hline Marital status [MARI] & 0.2539 & 0.3251 & 0.781 & 0.812 & 0.0025 \\
\hline Age square [AGESQ] & -0.0052 & 0.0032 & -1.628 & 0.568 & 0.0012 \\
\hline Education [EDU] & -0.0019 & 0.0725 & -0.027 & 0.978 & 0.0142 \\
\hline Number of dependants [NDEP] & 0.0562 & 0.0481 & 1.168 & 0.796 & 0.1420 \\
\hline Income [INCOM] & $-0.0515^{\star * *}$ & 0.0033 & -15.375 & 0.001 & 0.0821 \\
\hline Perception of rate [PRATE] & 0.1876 & 0.1345 & 1.395 & 0.592 & 0.0021 \\
\hline Awareness of penalty [PNALTY] & $-0.1289^{\star * *}$ & 0.0230 & -5.604 & 0.005 & 0.2011 \\
\hline Location of property [LOCA] & $-0.6786^{\star *}$ & 0.1982 & -3.424 & 0.020 & 0.3521 \\
\hline Value of property [VALUE] & $-0.0025^{\star *}$ & 0.0001 & -20.976 & 0.032 & 0.2502 \\
\hline Major use [MUSE] & $-8.5984^{*}$ & 4.7592 & -1.807 & 0.097 & 0.1210 \\
\hline Constant & -23.2278 & 17.8872 & -1.299 & 0.625 & - \\
\hline $\begin{array}{l}\text { Pseudo R }{ }^{2}=0.5528 \\
\text { Prob>Chi }{ }^{*}=0.000210 \\
\text { Numberof observations }=528\end{array}$ & & & & & \\
\hline
\end{tabular}

Source: Field Survey, 2013

Note: The asterisks indicate level of significance. *** is significant at $1 \%$, ** significant at $5 \%$ and * is significant at $10 \%$. 
In all, five out of the ten explanatory variables exhibit a statistically significant effect on the likelihood of property rates default by interviewees. Gender exhibits a significant relationship with the likelihood of default: and male property owners are about 5\% more likely to default than their female counterparts. One possible explanation is that male property owners may be less afraid of the consequences of not paying than female property owners. Another factor may be the matrilineal property inheritance and ownership regime that prevails in the study area as property owned by males are inherited by their sisters' children not their own children. Male property owners may not be motivated or encouraged by their household members (wife and children) to pay property rate. This finding is consistent with that of Atawodi and Ojeka (2011) in Nigeria, who found that women there are more likely to pay taxes and levies than men.

The coefficient of awareness of a penalty for non-payment exhibits a negative significant relationship with property rates payment default. Those who are aware of the penalty realise that it is more expensive if they fail to pay and the assembly decides to prosecute them, leaving them worse off. Property owners who are aware of the penalty for non-payment of property rates have a $20 \%$ higher likelihood of payment than those who are not aware, as indicated by the marginal effect. Pope and Abdul-Jabbar (2008) arrived at a similar conclusion in Malaysia, finding a positive relationship between tax compliance and awareness of penalty for non-payment in that country.

In the case of the 'major use' variable, the coefficient exhibits the expected sign and is found to be significant at the $1 \%$ level. It appears that owners of commercial properties are more likely to pay their rates than owners of residential property, which do not generate any income. Owners of properties mainly used for commercial purposes are $12 \%$ less likely to default on payment of property rates than their counterparts with properties mainly used for residential purposes. This finding supports that of Marti (2010), which also indicated that, in Kenya, commercial property owners are more likely to pay property rates than residential property owners.

The estimated coefficient and probability value on the location variable revealed that owners of properties in new sites or new towns are less likely to default than those whose properties are situated in an old town. This may be because owners of properties situated at a new site tend to have higher incomes, since they are developing these properties themselves, whereas properties at old sites are mostly inherited properties. The marginal effect is that owners of property at new sites are about 35\% less likely to default than their counterparts with properties in the old sites.

The value of the property, as expected, was found to be negatively related to probability of default and is significant at the $1 \%$ level. This may be explained by the fact that the higher the value of the property the more likely the owner is to be able to afford the property rates. Similarly, the income variable is also negatively related and significant at the $5 \%$ level. Based on the marginal effect, as the 
value of the property increases by one unit (GHS1) the likelihood of default decreases by $25 \%$; and as income increases by one unit the likelihood of default also decreases by $0.8 \%$.

\section{Conclusion and Policy Implications}

This study contributes to the debate on improving IGF through property rate collection for district assemblies in Ghana. Specifically, the study examines the socioeconomic characteristics of property owners in the Ashanti Region. In addition it identifies factors which influence default on property rates payment by property owners in the region.

Descriptive analysis of survey data collected in six districts of the region revealed that about $72 \%$ of the respondents did not pay property rates in 2012, contributing to a low level of IGF mobilisation. As a consequence of this low level, most of the assemblies were unable to deliver their budgeted expenditure on developmental projects financed from IGF.

Due to the high cost of property ownership, as well as low farm income levels, only a few farmers own property. The majority of the property owners are government and private sector employees. The study also suggested that more residential development is taking place at new sites than old sites, as over $67 \%$ of the properties surveyed were residential and more than half of these were located in new sites.

The findings suggest that wealthy or better-off property owners who are aware of the penalty, and whose property is located at the new sites are more likely to pay their property rates, as the regression results show a strong influence of education, income level, and awareness of the penalty of default on payment levels.

In terms of designing policies to improve IGF through property rates collection, the assemblies should develop campaigns to educate property owners on the need to pay and the penalty associated with non-payment of property tax. They should particularly target owners at new sites and those with commercial properties. Furthermore, the assembly should enforce the law and ensure defaulters are charged and penalties paid.

\section{Acknowledgements}

The authors are especially indebted to the management of the following municipal and district assemblies - Adansi North; Ahafo Ano North; Ejisu-Juaben; Ejura/Sekyedumase; Asante Akim South and Kwabre - for the information they provided with regard to property rates collection. They are also grateful to all the enumerators who assisted in data collection. Finally, the authors would like to thank all respondents without, whose co-operation this study could not have taken place. 


\section{References}

Ahafo Ano North District Assembly (2014). 2013 Financial Report

Appiah, J., Ayee, A., Baah-Wiredu, K., Martin, S. J. and Trollegaard, S. (2004). Fiscal Decentralisation and Sub-National Government Finance in Relation to Infrastructure and Service Provision in Ghana. The National Association of Local Authorities in Denmark (NALAD) and the Center for Democracy and Development (CDD) Ghana.

Atawodi, O.W. and Ojeka, S.A. (2011). Factors That Affect Tax Compliance among Small and Medium Enterprises (SMEs) in North Central Nigeria International Journal of Business and Management Vol. $7(12) 87-96$

Ayee, J.R.A. (2008). The balance sheet of decentralization in Ghana. In S Fumihiko (Ed.) Foundations for local governance decentralization in comparative perspective. Physica-Verlag, 223-258. doi: http://dx.doi.org/10.1007/978-3-7908-2006-5_11

Bahl, R. (2009). Property Tax Reform in Developing and Transition Countries, Fiscal Reform and Economic Governance Project, United States Agency for International Development.

Bird, R. and Slack, E. (2002). Land and property taxation around the world: A review, Journal of Property Tax Assessment and Administration, 7(3)31-80.

Boamah, N.A. (2013). Land use controls and residential land values in the Offinso South Municipality, Ghana. Land Use Policy (2013), http://dx.doi.org/10.1016/j.landusepol.2012.12.016

Chipeta, C. (2002). The Second Economy and Tax Yield in Malawi, Research Paper No.113, African Research Consortium, Nairobi.

Crawford, G. (2004). Democratic Decentralisation in Ghana: Issues and Prospects; POLIS Working Paper No. 9, University of Leeds.

Davis, P.T., McCluskey, W.J. and Lim, L. C. (2004).Residential Property Taxation: A Capital Value Banding Approach, Journal of Property Tax Assessment and Administration. 1 (3) 51-64.

Duncan, C.R. (2007). Mixed outcomes: The impact of regional autonomy and decentralization on indigenous ethnic minorities in Indonesia. Dev. Change, 38(4): 711-733. doi: http://dx.doi.org/10.1111/j.1467$\underline{7660.2007 .00430 . x}$

Ellis, P., Mihaly, K. and Lee, A. G. (2007). Property Taxes in the Large Cities of Punjab Province, Pakistan, Journal of Property Tax Assessment and Administration, 4(2) 31-51

Fjeldstad, O.H. and Semboja, J. (2001). Why People Pay Taxes. The Case of the Development Levy in Tanzania, World Development. 299(12) 2059-2074. doi: http://dx.doi.org/10.1016/S0305750X(01)00081-X

Ghana Statistical Service (2012). 2010 Population and Housing CensusSummary Statistics, Ghana Statistical Services, Accra, Ghana

Illinois Department of Revenue (IDR), (2001).The Illinois Tax System, A General Guide to the Local Tax Cycle, Office of Local Government Services.

Lall, S. V. and Deichmann, U. (2006). Fiscal and Distributional Implications of Property Tax Reforms in Indian Cities, Working Paper No. 39 April 2006, National Institute of Public Finance and Policy, New Delhi

Mathur, O. P., Bahl, R., Thakur, D. and Rajadhyasksha, N. (2009). Urban Property Tax Potential in India, New Delhi: National Institute of Public Finance and Policy.

Marti, L. O. (2010). Taxpayers' attitudes and tax compliance behaviour in Kenya. African Journal of Business \& Management, (1)112-122.

McCluskey, W. J. and Bevc, I. (2007). Fiscal decentralization in the Republic of Slovenia: an opportunity for the property tax, Property Management, 25(4) 2007, 400-419.

McCluskey, W., Franzsen, R., Johnstone, T., and Johnstone, D. (2003). Property Tax Reform: the Experience of Tanzania, Our Common Estate, July 2003.

Monkam, N. F. (2009). Property Taxation in Senegal: Legislation and Practice, Journal of Property Tax Assessment and Administration, 8(3) 41-60. 
Mou, C. (1996). Major Property Tax Issues in Africa, Property Tax in Eastern and Southern Africa: Challenges \&Lessons Learned, Working Paper, No.2, Harare Zimbabwe: Municipal Development Programme, 4-9.

Nagler, J. (1994).Interpreting probit analysis. New York University. Availablewww.nyu.edu/classes/nagler/quant 2/notes/probit1.pdf .

National Development Planning Commission (NDPC), (2010). The Implementation of the Growth and Poverty Reduction Strategy (GPRS II) 2006 - 2009: Annual Progress Report. Accra

Needham, B. (2000). Land Taxation, Development Charges, and the Effects on Land-Use, Journal of Property Research, 17(3) 241-257. doi: http://dx.doi.org/10.1080/09599910050120000

Olowu, D. and Wunsch,J. S. (2008). Local Governance in Africa: The Challenges of Democratic Decentralization. Boulder: Lynne Rienner 310 pp ISBN: 978-1-58826-173-1

Pope, J., \& Abdul-Jabbar, H. (2008). Tax Compliance Costs of Small and Medium Enterprises in Malaysia: Policy Implications. School of Economics \& Finance, working paper Series No 08.08 Curtin University of Technology

Trasberg, V. (2004). Property and land taxation in the Baltic States, Journal of Property Tax Assessment and Administration, 1 (2): 31-43. 